\title{
An International Comparison of Responses to the Covid-19 Pandemic by Universities and Schools
}

\author{
Fatima Al-Qaoud ${ }^{1,2}$, Andrew Carruthers ${ }^{2}$, Mumtaz Kamala², and Raed Abd-Alhameed ${ }^{2,3}$ \\ \{fnhalqao@bradford.ac.uk ${ }^{1,2}$,A.Carruthers@bradford.ac.uk², m.a.kamala@bradford.ac.uk ${ }^{2}$ \}
}

\author{
Kuwait University, Block 4, Al-khaldiya, Kuwait ${ }^{1}$ \\ Faculty of engineering and informatics, University of Bradford, Bradford, BD7 1DP, UK ${ }^{2}$ \\ Information and Comms Eng. Dept., Basrah University College of Science and Technology, Basrah \\ 24001, Iraq $^{3}$.
}

\begin{abstract}
This paper presents responses of several countries to the Covid-19 pandemic in educational institutions, and how universities and schools strove to complete the academic year during the pandemic. The pandemic forced institutions throughout the world to shift to fully online learning for students in schools, colleges, and universities. This paper also presents a comparison of different responses in universities and schools when implementing full online learning. Online platforms have been used by students and teachers, which requires gaining technical competencies and training courses to provide continuity of learning and teaching to complete the current academic year 2019/2020. Several countries such as the UK, Italy, Spain, Australia, and the USA have adopted various responses in their educational institutions during the Covid-19 pandemic to complete the academic year 2019/2020. Benefits of some implementations of fully online learning will also be presented, besides the concept of 'Smart City' as defined in academic research.
\end{abstract}

Keywords: Online learning, online environment, online system, ICT, IT, self-regulation, technology, education, Smart City, virtual environment, and Covid-19 pandemic.

\section{Introduction}

Since the Covid-19 pandemic first appeared in late 2019 in Wuhan, China, most countries have been forced to suspend schools, colleges, and universities for an unknown period to limit the spread of the virus. However, most of the developed countries such as the USA, the UK, Singapore, Japan, and developing countries such as Kuwait, Saudi Arabia, Qatar, and the United Arab of Emirates have resumed their school services in 2020 in different scenarios and at different times to complete the unfinished the academic year of 2019/2020 through online learning. To comply with the Covid-19 pandemic lockdown regulations, most educational institutions have been obliged to shift quickly to online learning to complete the current academic year 2019/2020. During the pandemic, countries which had already implemented a blended learning (BL) strategy, were generally better prepared to effectively make the transition to full online course delivery. Nevertheless, there were wide variations in how these countries had adopted BL and there is, as yet, no standardized approach to its implementation [1].

According to Lassoued [2], Covid-19 is a serious respiratory illness syndrome that can infect humans through being close to another person who is either infected or carrying the virus without exhibiting symptoms. Recovery following infection does not guarantee immunity 
against being re-infected. The World Health Organization (WHO) [3] announced that this syndrome, caused by a coronavirus (SARS-COV-2), Covid-19 is an ongoing widespread disease that emerged in December 2019 in Wuhan, China, and then spread to all countries throughout the world. WHO declared that all countries would have to coexist with the Covid-19 pandemic until a vaccine could be found [3]. Fortunately, in 2021, certain countries have released several vaccines. The best-known vaccines are Pfizer, a product of Germany, and AstraZeneca, a product of the UK, in addition to vaccines from China and other countries. As a consequence, it is expected that all countries will resume normal life, including returning to schools, colleges, and universities within 2021.

Despite the advantages offered by full online learning to maintain the continuity of the educational process, other crucial advantages have been absent for students who were accustomed to having regular in-school activities [4]. The Organization for Economic Cooperation and Development (OECD) has reported that learning losses from school closure have affected students equating to a 3\% drop in income over their lifetime [5]. Professional societies have strongly promoted regular in-school learning, considering Covid-19 rules and regulations in keeping the social distance among students and staff $[6,7]$.

It is important to shed light on how students regulate their time to accommodate a new form of learning such as fully online learning through systems and applications, taking all information and instructions from teachers to learn how to solve problems in mathematics, how to understand and comprehend information related to all other subjects remotely through an online system. Zimmerman and Schunk [8] defined self-regulation as a systematic exertion that students are making to control their learning process and effectively self-regulate to accomplish meaningful learning objectives. Self-regulation can take place between students and content, student and student, and student and instructor [9-12].

This work highlights different respondents of higher educational institutions to the Covid19 Pandemic, as well as school respondents, besides, benefits gained of fully online learning and teaching during the Covid-19 Pandemic. Smart cities have been frequently used in educational researches and will be also presented in this work. Furthermore, this work will compare different respondents of universities and schools to Covid-19 among developed countries in Europe, Australia, and the USA.

\section{Universities and Higher Education Respondent to Covid-19}

Different strategies have been adopted by several countries throughout the world during the COVID-19 pandemic to keep the educational process. Universities have been affected by the pandemic just as other colleges, schools, and social activities in the community. Universities have adopted digital interfaces to deliver learning and teaching to their students [13]. In the future, global higher education will have to take account of the impact of Covid-19 on universities and educational institutions to meet the challenges and support benefits to satisfy successful online learning [14].

In this section, we will highlight different responses of educational institutions in some countries of Europe such as the UK and the Republic of Ireland (ROI), Italy, Germany, as well as Australia, and the USA.

\subsection{The United Kingdom and Republic of Ireland (ROI)}

The British government has closed schools with some exceptions for students with special circumstances [15]. Morgan [16] reported that students may face issues regarding admissions to the university, but Bothwell [17] asserted that universities must be more flexible to facilitate 
admission procedures, recommending more support and opportunities related to international students. All social facilities, restaurants, and other institutions were closed on 20 March 2020 but with the government delivering support packages for staff and workers affected by the social distancing and quarantine requirements [18]. UK universities faced uncertain times for the number of international students as well as domestic students who faced difficulties in attending the university due to travel restrictions [19]. Later, [19] declared transforming to an online environment for teaching and working remotely, delaying graduation occasions, canceling open days, and rescheduling examination dates.

In the Republic of Ireland (ROI), Trinity College Dublin [20] closed its buildings and transferred to online learning as the first Irish university that took immediate action in response to the threat presented by Covid-19. On 12 March 2020, Andrew Deeks as a president professor at University College Dublin (UCD) announced to all staff and students that all buildings of the university would be closed from 13- 29 March 2020 except for the library and medical research facilities. According to Deeks et al. [21], on 16 March 2020, presidents of 21 higher education institutions with the collaboration of two student unions distributed emails to all registered students advising them how to remain safe during the Covid-19 pandemic and announcing their intention to make EdTech available as a new educational technology to be used for remote learning and assessment. A decision has been taken by many Irish higher educational institutions [20, 2224], that all lectures and assignments must take place in a virtual and online environment until the end of the current academic year on 31st August 2020.

It is important to identify strategies for implementing anatomical education for medical students in a virtual environment. A total of 14 different universities have participated in a SWOT analysis (Strength, Weakness, Opportunity, Threat). According to [25], universities in the UK closed on 16 March, while in the ROI they closed on 12 March 2020. They shifted to online learning and communication provision through platforms supporting emails and webpages. Chatziralli [26] asserted that platforms such as Skype, Zoom, Cisco WebEx, Go to Meeting, Microsoft Teams, and other platforms have been used heavily during Covid-19. The highest percentage use was for Zoom that reached (55.8\%) followed by Microsoft Teams (15\%), meaning that Zoom was the most preferred platform for educational purposes. However, the curriculum of anatomy in the UK and the ROI depended on a system, problem, and traditional regional format; they used some platforms to deliver information for their students such as Panopto Platform (50\%), Zoom (36\%), Collaborate Ultra (36\%), and Big Blue Button (36\%). Human bodies have not been used for anatomy in Lancaster University Medical School, Peninsula College of Medicine and Dentistry, and the University of Limerick Medical School [27], while many resources have been used by UK and ROI to deliver teaching with different percentages. Based on Longhurst's study [28], the highest percentage was (42.9\%) for universities that used both cadaveric and 3D virtual resources, followed by universities that used digitized cadaveric resources only $(28.6 \%)$. The lowest percentage was $(7.1 \%)$ for universities that used $3 \mathrm{D}$ virtual resources only.

\subsection{Germany}

Since 16 states follow governmental rules and regulations independently, different procedures have been applied to hinder the spread of the Covid-19 pandemic. Many of the 424 higher educational institutions in Germany have taken independent decision-making to sustain the educational process [29]. However, the government of Bavaria enforced lockdown on 21 March 2020. According to [30], a valuable case study was presented on the wise management of all challenges that faced the higher education sector during the Covid-19 pandemic. On 12 March 2020, the University of Passau (Bavaria) decided that face-to-face teaching would be temporally 
suspended. The university adopted online working for staff, while extended time has been given for theses, dissertations, and all written assignments because the library was closed. Additionally, oral examinations have been suspended, while the number of written examinations was decreased to be at a minimum level as the university declared that buildings would be closed from 24 March to 19 April 2020 and virtual teaching was being established to continue the summer semester [30]. Also, Lower Saxony's University of Gottingen suspended teaching with immediate effect except for meetings and conferences were held through video conferencing technology [31].

Higher education did not prepare for managerial strategies, or expand efforts to train teachers; besides, no technical rules or regulations have been set to involve in the digital world, and coping with digitalization required concentrating on innovation and "modernization" [32] of learning and teaching in the context of higher education. German universities have been recommended to improve their digitalization strategies for teaching and learning [33]. To hasten the process towards a digital and online environment in German universities, the practice of Emergency Remote Teaching was highly recommended to build an IT infrastructure [33]. Moreover, on 22 March, Heidelberg University has closed all buildings and prepared for online learning [34].

\subsection{Italy}

On $4^{\text {th }}$ March 2020, the Italian government compelled all schools and universities to close and terminate activities involving close physical contact. The universities of Milan, Turin, and Bologna have adopted online learning and teaching including examinations through the web [35]. Italy is one of the countries that have been highly infected by Covid-19 and the first case was recorded on $31^{\text {st }}$ Jan 2020 [36]. According to [37], the Italian Minister of University and Research decided that universities would adopt online lessons starting from 2 March while graduate students would use Skype. However, a few universities kept their usual learning and teaching activities such as the university of Basilicata that set up thermal scanners to screen for infections [38].

Italian higher education has adopted the strategic model of distance learning to provide urgent remote education as a sustainable and dependable strategy [39]. According to [40, 41], sharing platforms enabled curriculum development through building new communities and authorized students for more accessible educational platforms. It is important to measure distance education in the context of advantages and disadvantages since it requires network collaboration, open access, and remote teaching. Nevertheless, they are susceptible to low completion rates, lowquality assurance, and limited measurable tools. Moreover, course content challenging, insufficient time, lack of a sense of community, and social impact were the most frequently reported reasons that caused dissatisfaction among learners [42-44].

Giovannella [45] conducted a study during Covid-19 to measure the fast and sudden transform from traditional physical learning to a fully online learning environment, including their perspectives and feelings regarding distance learning. A survey was distributed to bachelor students who studied the course "Educational Science of the University of Rome Tor Vergata, Italy. Because of the lockdown, the university shifted to online learning. Different devices have been used by students such as smartphones, tablets, desktop computers, and laptops before and after the Covid-19 pandemic. It was observed that utilization of the smart-phones has reduced to half (45\%) during Covid-19 than the normal time (90\%) as shown in Fig 1. [45]. 


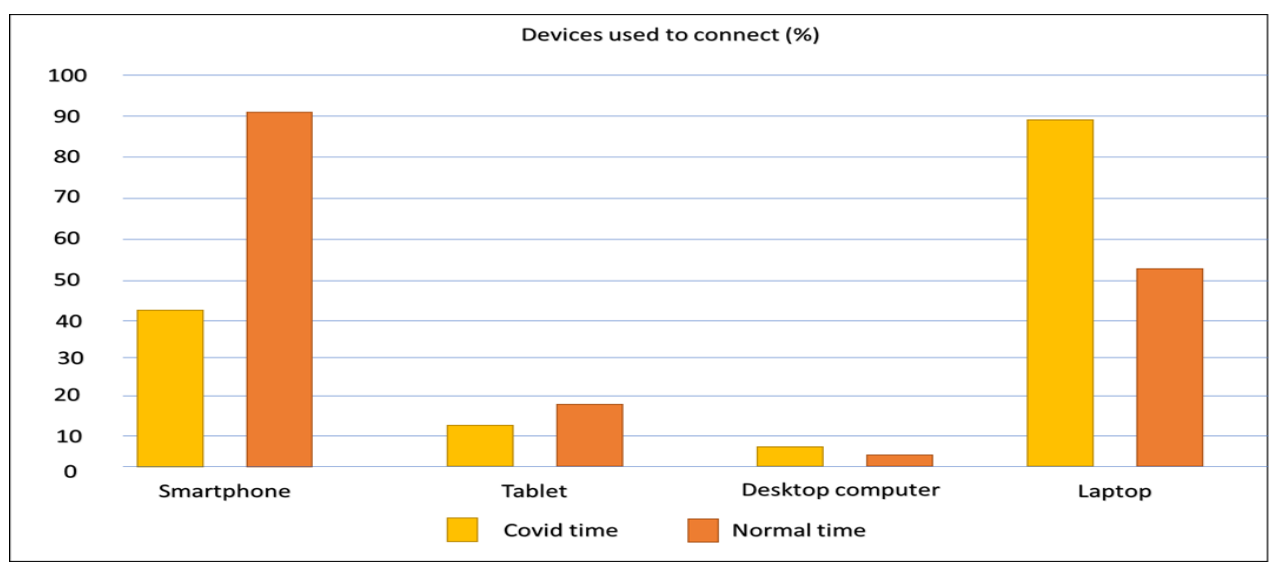

Fig. 1. Percentage of the devices used by the students to participate in virtual didactic activities (Adopted from [45]).

On the other hand, the utilization of laptops increased to reach about $90 \%$ from its previous level of $53 \%$. This shows that students preferred using laptops during Covid-19 than their smartphones. Furthermore, students preferred to take lessons and exams face-to-face rather than in an online environment as shown in Fig 2. [45]. The study revealed that university students are prepared to use a new educational format.

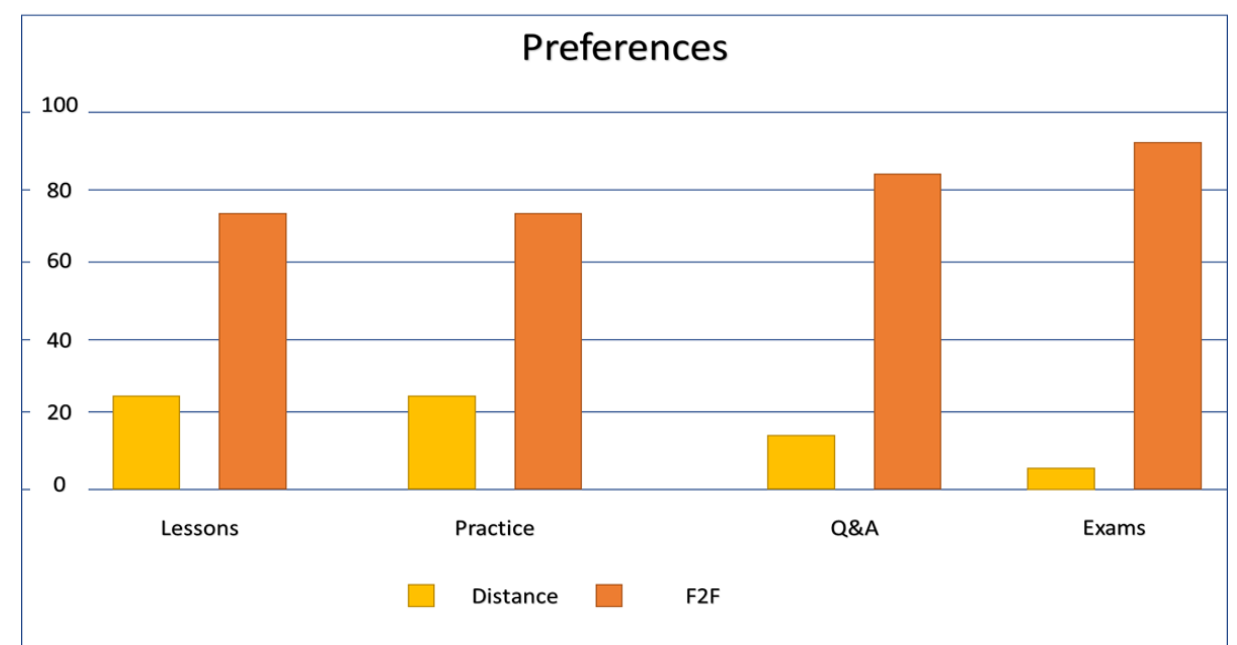

Fig. 2. Students' preferences in the percentage of distance vs. f2f (Adopted from [45]).

\subsection{Australia}

The universities in Australia did not shift to online learning immediately because the government prohibited public indoor gatherings to be less than 100 persons on $18^{\text {th }}$ March [46]. Therefore, different procedures have been taken by different universities. Since there are international and domestic students, several regulations have been applied to each case. The University of Sydney began with fast cleaning activities after their first case of infection of a 
student with Covid-19 [47]. At this stage, the universities began to adopt other options for learning. Some of the universities such as Macquarie University, Monash University, and Victoria University stopped learning activities for a period to design an online learning environment [48-50]; however, other universities such as the University of Queensland and the University of Technology, Sydney decided to continue learning by face-to-face communication but with social distancing protocols accompanied by online recordings [51, 52]. On the other hand, the Australian National University and the University of Tasmania made rapid improvements towards implementing online learning without any delay $[53,54]$.

\subsection{United States of America}

The United States of America, just like other Western Countries, responded to the Covid-19 pandemic in March 2020 despite earlier suspicions of the first infected Chinese student with Covid-19. With the dramatic rise of the infection rate [55], Harvard University [56] declared on 10 March that all delivery of learning would have to shift to a full online environment by 23 March 2020 just as Massachusetts Institute of Technology (MIT), Yale, Princeton, Stanford, and the University of California had done. However, Southern Oregon University [57] took speedy action to shift to online on 19 March. Other universities decided on different dates in March for online learning based on the analysis of higher education in Texas [58].

The level of self-regulation has a strong correlation with student motivation in the Application of Technology in Education at a university in the USA and represents a key predictor of the effectiveness of learning outcomes [59]. Since confidence or self-efficacy in learning is strongly related to self-regulation $[8,60]$, students with high confidence are inclined to become involved in more metacognitive and interaction regulation than students with less confidence in online learning. The self-efficacy of students who study online is positively increased with more exertion and cognitive management [61] and building the strategy of improvement in a selfpaced online learning environment [62]. Therefore, motivation profiles are crucial for students' self-regulation and in their accomplishment of effective learning results [8, 60, 63-66]. Furthermore, students with higher motivation show a better level of self-regulation between students and content and self-regulation between students and instructor than those who have less motivation. Similarly, students with medium motivation are more highly self-regulated with content and instructor than those with lesser motivation levels. In conclusion, according to students' motivation profiles, the predictability of self-regulation ineffective learning results have different levels. Thus, the motivation profile in online courses is most significant since they are significantly correlated to self-regulation [59]. Based on theoretical background and related studies, Chauhan [67] has proposed a research model evaluating 18 hypotheses to analyze the continuous intention of full-time business school students and faculty who shifted to online learning during Covid-19 circumstances. The Expectation Confirmation Model (ECM) and the Task-Technology Fil (TTF) framework have been built and tested to verify the continuance intention of full-time students and faculty of business schools. The study revealed that all hypotheses were supported and provided evidence that of students' focused study as well as faculty focused study.

\section{Schools Respondent to Covid-19}

In the academic year, 2019/2020, countries around the world have swiftly transformed from traditional learning through attendance schools to online learning through remote access because of the Covid-19 pandemic which prevented attendance to schools. Online learning requires sharing information among students through an online environment in a collaborative manner. Zhang et al. [68] defined Collaborative Learning (CL) as "a sort of social activities, 
including a network of students and educators, where individuals share and gain information". Therefore, culture could have fundamental impacts on the enhancement of CL among students and may influence their ability to communicate and interact with others [69].

According to [70], about 200 countries have closed schools with over $90 \%$ of learners being obliged to interrupt their education that used to take place regularly. It is estimated that about half a billion children [71] have been compelled to use a virtual learning environment at home, while families assumed a significant role as facilitators to assist their children to become involved in the new form of online learning. Most stakeholders such as parents, students, and teachers were unprepared to shift to a full online environment with variant levels of education [72]. Unfortunately, remote learning resources are not available for all families because they have lower income levels. However, even when online learning was available in the home, positive parental engagement was found to have an important impact on students to use online learning effectively and successfully.

\subsection{Schools in the UK}

It is important to highlight an exceptional experience of a school response in the UK during the Covid-19 pandemic since most schools had closed their doors and continued by offering online learning for the remainder of the semester [73]. According to Southall [73], some primary schools reopened schools on $1^{\text {st }}$ June for students aged (4-5, 5-6, and 10-11), whereas students in secondary schools aged (14-15 and 16-17) resumed attendance on $15^{\text {th }}$ June [74], and all other students received their learning at home through an online learning environment. A specific procedure has been taken by the government such that all students had to be back to school from $1^{\text {st }}$ September in England with no medical support in the place [75]. Nevertheless, students were obliged to wear masks and to apply social distance for their safety, and parents were recommended to avoid gathering outside the school. In addition, students and teachers have been located in groups called 'bubbles' to avoid large-scale infection [76]. In case that a student or a teacher was infected, all other members of that bubble had to be quarantined for 14 days and required to take a test when symptoms appeared. Despite the indication of a positive relation between cases in society and cases in the schools, it cannot be assumed that schools contributed to any great extent to infection in the community.

Kristine Macartney and her colleagues developed a study in the UK to estimate the infection of coronavirus among school students and early childhood education and care facilities in New South Wales, Australia, during the beginning of the pandemic. When online learning was adopted, the attendance rate of all opened facilities in the UK declined precipitously in schools during March 2020. Since the number of cases was identified, most of the educational facilities were closed. Results showed that schools and educational institutions may continue to remain open on the condition that rules and measures such as keeping proper social distance among students and isolation were being observed [77].

\subsection{Schools in Germany}

A large number of schools were closed in March 2020 due to Covid-19 pandemic restrictions; nevertheless, schools began to reopen gradually in May 2020 having extensive restrictions still in place and estimating the suitable time for complete closure. Since the learning landscape has generally changed due to the fast shift towards technological innovation and digitalization, the majority of schools in Germany have closed [78, 79]. According to [80-82], Germany, as with many other European countries (e.g., France and Italy) remained slow to shift to proper Information and Communication Technology (ICT). Therefore, digitalization in schools has recently become an important issue. A serious arrangement has been prepared to fill the 'gap' 
between students' conventional learning and improvements at school [83]. New teachers are capable of mastering challenges in this unprecedented situation and have successfully coped with the online learning environment during Covid-19 [84].

Germany's federal states decided to close all primary and secondary schools on 16 March 2020, then they reopened in April with protective procedures to prevent the spread of the disease. However, students of different ages were infected by Covid-19. During the reopening of schools, a proper evaluation of well-prepared protective procedures has been undertaken to estimate the effectiveness of measures to reduce the infection to make well-informed decisions. It is recommended that school reopening should be monitored in terms of their capability and the ability to fast test, track, and quarantine for any suspected Covid-19 cases and their contacts [85].

\subsection{Schools in Spain}

The Covid-19 pandemic also reached Spain and the government imposed lockdown there from 14 March to 10 May 2020, compelling all schools to shift to a virtual environment to continue learning in this new situation [86]. This unexpected situation has created a great challenge for educational institutions, teachers, and students in Spain to adopt an online environment strategy for learning and teaching [86]. Some countries have set up urgent plans to implement online learning; others such as China were not prepared for online learning and consequently, some constraints appeared because of the shortage of IT resources in schools and the lack of proper detailed plans to implement large-scale online education during unexpected circumstances [68]. In contrast, the Spanish Government obliged schools in Catalonia, as well as all regions in Spain, to adopt an online environment for learning and teaching [87]. In Catalonia, the law regulating the public schools' management takes place through a team that is arranged by the principal who is selected by a committee consisting of teachers, parents, and the administration. The principal is authorized to select the rest of the management staff such as teachers.

Cities are constantly changing, and with the spread of ICT, the concept of 'Smart City' is being mentioned more frequently in academic researches [88, 89]. Paskaleva [90] stated that "the term 'Smart City' focused on the relevance of ICTs for the achievement of more competitive status and a more sustainable development". Other researchers believed that the cultural and professional growth of individuals in a society is related to the smart city [91]. On the other hand, others related it with the effect of ICT and its evolution to the infrastructure [92]. However, [93] considered the smart city in terms of its relevance to ICT and its benefits to the users [94]. The European Parliament maintained that smart cities depended on the initiation and connection of human capital, social capital, and digital infrastructure to develop sustainable economic progress and a better lifestyle [95]. Covid-19 has marked a turning point in learning and teaching mechanisms [94]. Therefore, online psychoeducation should be considered by health authorities [96].

Olmos-Gomez [94] conducted a study in the city of Melilla, Spain to design and validate a Smart City tool to measure the effect of online learning on teaching during school closure, as well as to obtain descriptive results for the use of the Smart City tool for online learning and teaching purposes during Covid-19 pandemic, using Structural Equation Model (SEM). The participants were teachers from primary and secondary schools and university levels. The results indicated that the models used were highly reliable and validated; furthermore, the questionnaire used was very effective for teachers when using the Smart City concept.

\subsection{Schools in Estonia}


Estonia enforced emergency measures similar to those in other European countries during the Covid-19 pandemic. The government closed all schools on 16 March 2020 [97], and distance learning was recommended [98]. Lepp [97] states that distance learning is a sort of learning that includes controlled e-learning that is concentrated on knowledge and competencies using a virtual environment. The government of Estonia has obliged teachers as well as students to communicate through digital means to complete the school year by June 2020 [97]. According to the Ministry of Education and Research, Estonia [99], guidelines for teachers as well as school leaders were issued drawing on the fact that Estonia is considered as a highly digitized society that possessed the best IT- infrastructure implementing national e-services for its people. Therefore, shifting to online learning was quite straightforward and was sustained by the Estonian Lifelong Learning 2020 Strategic plan [100].

\subsection{Schools in the United States of America}

Schools in the USA also closed due to Covid-19 and used a new type of education which is virtual education $[101,102]$. However, there were some concerns that some students would not cope with online learning because their skills and competencies in receiving information via an online environment were under-developed [103]. It is crucial to use Google search data which is a high frequent representative search engage to measure how students and parents navigate through online resources in real-time [104]. Some students needed additional support to overcome educational obstacles caused by Covid-19, However, school leaders and policymakers have given priority access to home computers and broadband internet. Enhanced access involving the online learning environment will importantly assist to equalize learning opportunities and avoiding any educational gaps [104].

Calhoun [105] asserted that students in K-12 schools in Washington State, USA have adopted learning online on 17 March 2020 to continue the unfinished academic year 2019/2020. The University of Washington, School of Medicine (UWSOM) is one of two medical schools in the state, which covers WWAMI region which includes (Wyoming, Alaska, Montana, and Idaho). The university school took a crucial decision for its medical students by shortening the $3^{\text {rd }}$ year rotations and triage for the $4^{\text {th }}$ year electives, as well as adopting virtual clerkship to keep up the learning process.

Bol [106] believed that families with high educational qualifications were taking more time to help their children to use online learning facilities and features than families with lower educational qualifications. According to [103], 38\% of families with lower personal earnings stated that their children had massive online instructions, in comparison with higher-income families. Based on the three-parent survey items used to assess students' involvement in online learning, Domina [107] divided the survey into Enjoyed remote, complete assignments, and Log on each week. Fig 3. [107] illustrates how parents responded to all previous items taking relatively moderate disseminations. Therefore, Domina [107] suggested hard efforts to support students with strong and holistic learning opportunities that increased their academic and socioemotional development. It is found that educational policymakers must consider the risk of social quarantine for students and their families. 

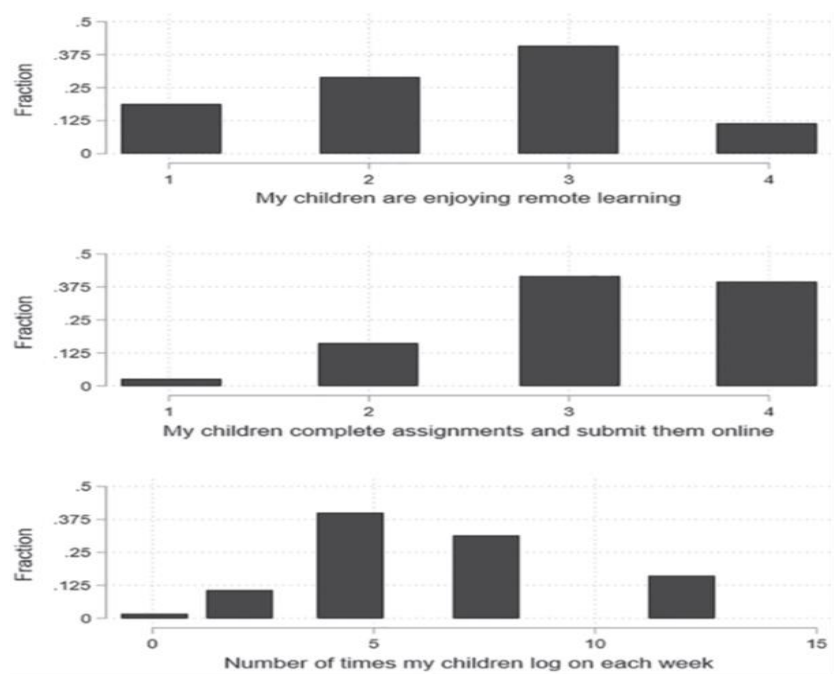

Fig. 3. Families' Reports about their Children Involvement in Online Environment (Adopted from [107]).

\section{Benefits of online learning during Covid-19 pandemic}

During Covid-19, all educational institutions were forced to shift to full online remote learning through a digital environment to complete the academic year 2019/2020. This required the availability of IT infrastructure and all related needs (e.g.: digital curriculum content, trained teachers, and students' technical skills) to implement online learning successfully. Despite the differences in availability across countries, many benefits have been gained during the Covid19 pandemic.

Distance learning or online education enabled students to discover their technical competencies and capabilities. Such capabilities help them to use managerial functions perfectly such as downloading and uploading files and documents. Online courses are more beneficial than video courses and open education because students can interact with their instructors with immediate responses to their questions. Social communication applications such as WhatsApp, E-mail, Facebook, and Instagram played a significant role in delivering information from instructors to students [108]. Stacey [109] indicated that the application of online learning is not restricted to crises, but is an alternative option to face-to-face education. Likewise, the most obvious benefits of online learning are that students are not restricted to time or a place, so they can have their education at anytime and anywhere [110].

The utilization of ICT tools helps to develop students' comprehension of instructional materials [111]. Moreover, simulation of real processes can be implemented through ICT and enables students to engage with the virtual world [112]. Thus, the acceleration of the technology interaction rate is required as well as the optimization of educational online applications considering any future crisis [113]. For parents, they show positive impressions and attitudes regarding online learning; they encourage valuable technical competencies for their children. Practicing for managerial computerized functions of online applications is highly recommended [114]. However, parents are worried about potential perilous content that may negatively affect children's beliefs and morals.

\section{Smart Cities}


The term 'Smart City' has been repeated more frequently in researches, since some experiences indicate that some cities considered themselves to be smart; thus, it is important to shed light on the definition, concept, and principles of the 'Smart City' from the perspective of academic research [115]. It is difficult to create the features that form an ideal smart civilized city because such features are based on the size of the city, accessibility to other cities, and accessibility to service centers; thus, population size and suitable functions to implement a smart city should be considered [116]. Additionally, smart people, smart economy, smart governance, and smart environment are involved in smart city construction [117].

Drawing on previous in-depth studies, Caragliu [118] assumed that similar projects and solutions have been defined using several different words but with close similarities with one another. For instance, intelligent city, wired city, and digital city have a similar meaning, however, similarities and differences were not determined yet. On the other hand, Chen [119] states that technology is the main driver for the smart city and in particular ICT, which enables connections to be made to different agents in the civilized arena and to provide technical services. The most significant agents are universities, research institutions, and companies with high technology [120, 121]. Dameri [115] defines a smart city based on three characteristics which are: terminology; components; boundaries and scope. Similarly, 'Smart Cities' are considered as ecosystems that are defined as interacted organisms' communities and their environment and described as a complicated formed network through interdependent resources [122]. Ecosystems consist of agents, organizations, material infrastructures, and symbolic resources that are independently gathered in a social system [123].

Lytras [124] conducted a study to discuss the smart city debate from citizens' awareness perspectives and their ability to use services available in the smart city. Several (102) highly educated participants from 28 countries participated in this study. The survey covered $60 \%$ of Ph.D. holders, followed by $28 \%$ of Masters' degree holders, the bachelor's degree holders represented only $4 \%$, while $2 \%$ represented undergraduates. Most of the respondents were from Europe and represented $44 \%$ of the sample, followed by Asia at 34\%. The most notable countries which represented $70 \%$ of the sample were: China, Spain, Greece, Taiwan, Saudi Arabia, Pakistan, Brazil, and the Czech Republic. The results showed that many concerns hindered those educated individuals from using these services. Therefore, it is suggested that based on the utility, accessibility, and efficiency of services, users of the smart city can be divided into three groups as advocates, concerned users, and apathetic.

\section{Results and Discussion}

Based on all navigated researches that have been conducted throughout the Covid-19 pandemic, all educational institutions such as universities and schools have been obliged to shift to fully online learning, whether they have satisfied the technical needs and IT infrastructure or not. However, different levels of students' comprehension and understanding will be recognized soon after they move to the second level in their education when the crisis has passed. 
Table 1. Comparison of Different Universities' Respondents to Covid-19 of several countries.

\begin{tabular}{|c|c|c|c|c|}
\hline Country & Institution & Respond en $t$ & $\begin{array}{l}\text { Date of } \\
\text { Action }\end{array}$ & Platform/Mean \\
\hline UK & UK universities & $\begin{array}{l}\text { - closed and shift to online } \\
\text { - delaying graduation occasions } \\
\text { - cancelling open days, and } \\
\text { reschedule examination dates. }\end{array}$ & $16 \mathrm{March}$ & $\begin{array}{l}\text { Online learning, Skype, Zoom } \\
(55.8 \%) \text {, Cisco WebEx, Go to } \\
\text { Meeting, Microsoft Teams } \\
(15 \%)\end{array}$ \\
\hline $\begin{array}{l}\text { Medical } \\
\text { Schools in } \\
\text { the UK }\end{array}$ & $\begin{array}{l}\text { - Lancaster University } \\
\text { Medical School } \\
\text { - Peninsula College of } \\
\text { Medicine and Dentistry } \\
\text { - University of Limerick } \\
\text { Medical School }\end{array}$ & $\begin{array}{l}\text { - teleteaching and telemedicine } \\
\text { modalities have been adopted } \\
\text { - shift to online }\end{array}$ & $16 \mathrm{March}$ & $\begin{array}{l}\text { - Panopto Platform }(50 \%) \\
\text { - Zoom }(36 \%) \\
\text { - Collaborate Ultra }(36 \%) \\
\text { - Big Blue Button }(36 \%) \\
\text { - cadaveric and 3D virtual } \\
\text { resources }(42.9 \%) \\
\text { - digitized cadaveric resource } \\
\text { only }(28.6 \%) \\
\text { - 3D virtual resource only } \\
(7.1 \%)\end{array}$ \\
\hline \multirow[t]{2}{*}{ ROI } & \multirow{2}{*}{$\begin{array}{l}\text { - Trinity College Dublin } \\
\text { - University College } \\
\text { Dublin } \\
\text { - University College Cork } \\
\text { - Queen's University }\end{array}$} & \multirow[t]{2}{*}{ - closed and shift to online } & \multirow[t]{2}{*}{$12 \mathrm{March}$} & $\begin{array}{l}\text { - virtual, online learning } \\
\text { - EdTech, virtual, online } \\
\text { learning }\end{array}$ \\
\hline & & & & $\begin{array}{l}\text { - virtual, online learning } \\
\text { - virtual, online learning }\end{array}$ \\
\hline \multirow{3}{*}{ Germany } & Government of Bavaria & - enforced lockdown & $21 \mathrm{March}$ & - Not mentioned \\
\hline & $\begin{array}{l}\text { University of Passau } \\
\text { (Bavaria) }\end{array}$ & $\begin{array}{l}\text { - building s closed } \\
\text { - delayed face-to-face teaching } \\
\text { - online working for staff } \\
\text { - extended time for theses, } \\
\text { dissertation, and assignments } \\
\text { - library closed } \\
\text { - oral ex aminations suspended } \\
\text { - examinations decreased }\end{array}$ & $\begin{array}{l}24 \text { March- } \\
19 \text { April }\end{array}$ & -Virtual teaching \\
\hline & $\begin{array}{l}\text { University of Gottingen } \\
\text { Heidelberg University }\end{array}$ & $\begin{array}{l}\text { - suspended teaching } \\
\text { - recommended to improve their } \\
\text { digitalization strategies } \\
\text { - building closed } \\
\text { - prepare online learning }\end{array}$ & $\begin{array}{l}\text { Not } \\
\text { mentioned } \\
22 \mathrm{March}\end{array}$ & $\begin{array}{l}\text { - video conferencing } \\
\text { technology } \\
\text { - prepare online learning }\end{array}$ \\
\hline \multirow[t]{3}{*}{ Italy } & Italian government & $\begin{array}{l}\text { - enforced all schools and } \\
\text { universities to close and } \\
\text { terminate }\end{array}$ & $4 \mathrm{March}$ & - Not mentioned \\
\hline & $\begin{array}{l}\text { The universities of Milan, } \\
\text { Turin, and B ologna }\end{array}$ & - adopted online lessons & $2 \mathrm{March}$ & $\begin{array}{l}\text { - Skype } \\
\text { - distance learning }\end{array}$ \\
\hline & $\begin{array}{l}\text { University of Rome Tor } \\
\text { Vergata }\end{array}$ & $\begin{array}{l}\text {-1ockdown } \\
\text { - shifted to online learning }\end{array}$ & 4 March & - online environment \\
\hline \multirow{5}{*}{ Australia } & Australian universities & - shifted to online learning & \multirow{5}{*}{$18 \mathrm{March}$} & $\begin{array}{l}\text { - different procedures } \\
\text { - online recording and } \\
\text { offerings }\end{array}$ \\
\hline & University of Sydney & - fast cleaning activities & & - other options of learning \\
\hline & $\begin{array}{l}\text { National University } \\
\text { University of Tasmania }\end{array}$ & $\begin{array}{l}\text { - no delays } \\
\text { - fast improvem ents towards } \\
\text { online learning }\end{array}$ & & - online environment \\
\hline & $\begin{array}{l}\text { Macquarie University } \\
\text { Monash University } \\
\text { Victoria University }\end{array}$ & $\begin{array}{l}\text { - stopped learning for a while } \\
\text { just to design an online learning } \\
\text { environment }\end{array}$ & & - online environment \\
\hline & $\begin{array}{l}\text { University of Technology } \\
\text { Sydney } \\
\text { University of Queensland }\end{array}$ & $\begin{array}{l}\text { - continued face-to-face } \\
\text { learning with social distance } \\
\text { protocols }\end{array}$ & & $\begin{array}{l}\text { - online recording and } \\
\text { offerings }\end{array}$ \\
\hline \multirow[t]{2}{*}{ USA } & $\begin{array}{l}\text { Harvard University } \\
\text { Massachusetts Institute of } \\
\text { Technology (MIT), Yale, } \\
\text { Princeton, Stanford, and } \\
\text { the University of } \\
\text { California }\end{array}$ & $\begin{array}{l}\text { - shift to full online } \\
\text { environment }\end{array}$ & $23 \mathrm{March}$ & \multirow[t]{2}{*}{ - online environment } \\
\hline & Oreg on University & - shift to online & 19 March & \\
\hline
\end{tabular}


The results indicated that all educational institutions in the UK, ROI, Germany, Italy, Australia, and the USA have been forced to transition to fully online learning to continue the remainder of the academic year, except for the University of Technology, Sydney, and the University of Queensland in Australia, which continued face-to-face learning but complying with social distance protocols as shown in Table 1. below. Additionally, Table.1 shows that Italy was the first European country that responded to Covid-19 and that was on 2 March 2020. Since the pandemic started there, Italy closed all schools and universities and adopted online learning. On the other end of the scale, the USA was the latest country that took action in response to the pandemic on 23 March 2020. USA universities have also shifted to fully online delivery to continue teaching and learning to complete the academic year. The most preferable platform used in the UK was the Online learning, Skype, Zoom (55.8\%), followed by Cisco WebEx, Go to Meeting, Microsoft Teams (15\%). However, medical schools used the Panopto platform which reached (50\%), followed by Zoom, Collaborate Ultra, and Big Blue Button at $36 \%$.

Table 2. School respondents to Covid-19 in different countries.

\begin{tabular}{|c|c|c|}
\hline Country & School Respondent & Citation \\
\hline The UK & $\begin{array}{l}\text { - closed and continue online learning } \\
\text { - some primary schools reopened schools on 1st June } \\
\text { - students of secondary schools attended the school on } 15 \text { th June } \\
\text { - students implemented online environment. } \\
\text { - on 1st September, students attend schools with no medical support in the } \\
\text { place, but obliged to wear masks and apply social distance } \\
\text { - students and teachers have been located in groups called 'bubbles' }\end{array}$ & $\begin{array}{l}{[77]} \\
{[77]} \\
{[78]} \\
{[78]} \\
{[79]} \\
{[80]}\end{array}$ \\
\hline Germany & $\begin{array}{l}\text { - all primary and secondary schools closed in } 16 \text { March } 2020 \\
\text { - reopened on April with protective procedures } \\
\text { - students were infected by covid-19 in different ages } \\
\text { - During reopening schools, proper evaluation of well-prepared protective } \\
\text { procedures has been taken. } \\
\text { - closed due to fast shift in technological innovation and digitalization }\end{array}$ & {$[82],[83]$} \\
\hline Spain & $\begin{array}{l}\text { - lockdown from } 14 \text { March to } 10 \text { May } \\
\text { - all schools to shift to virtual environment } \\
\text { - a study developed using Smart City concept }\end{array}$ & $\begin{array}{l}{[90]} \\
{[90]} \\
{[99]}\end{array}$ \\
\hline Estonia & $\begin{array}{l}\text { - all schools closed in } 16 \text { March } \\
\text { - distance learning has been approved } \\
\text { - guidelines for teachers were assigned to implement online teaching }\end{array}$ & $\begin{array}{l}{[101]} \\
{[102]} \\
{[103]}\end{array}$ \\
\hline USA & - schools have been closed & {$[105],[106]$} \\
\hline $\begin{array}{c}\text { Schools in } \\
\text { Washington State }\end{array}$ & - resumed learning for $\mathrm{K}-12$ students through online on $17 \mathrm{March}$ & {$[109]$} \\
\hline
\end{tabular}

Similarly, schools had to respond urgently to the Covid-19 lockdowns just like universities, however, some reopening scenarios have been applied in the UK and Germany as we can see in Table 2. below. For instance, in the UK, all schools closed and continued education through the online environment but later, on $1^{\text {st }}$ June, the primary schools reopen for students [73], also students in secondary schools attended their classes on 15th June and all other students have received their learning remotely in an online environment [74]. However, the government obliged all students to return to schools on 1st September with no medical support in the place but obliged them to wear masks and comply with social distancing regulations [75]. Likewise, 
in Germany, all primary and secondary schools closed on 16 March 2020 and reopened in April with protective procedures, despite well-prepared protective procedures that have been taken, students were infected by Covid-19 at different ages, proper evaluations have been taken to assess the effectiveness of decisions to reduce the infection and to make appropriate decisions for the future [85]. In contrast, Spain, Estonia, and the USA have implemented online learning to complete the academic year without physical buildings reopening. Spain has implemented a notable experience during Covid-19 to design and validate a 'Smart City' tool in the city 'Melilla' for learning purposes. According to Olmos-Gomez [94], the success of this experience has been achieved.

\section{Conclusion}

The covid-19 pandemic has spread throughout the world for almost two years. It expanded gradually from Asia to Europe and has reached America. Despite some vaccines having been released to prevent the infection of this disease, no one has yet confirmed the end of this pandemic. Educational institutions such as universities, colleges, and schools have been forced to shift to online learning during the pandemic. Developed and developing countries have different levels of IT infrastructure preparations; therefore, different levels of students' outcomes will be observed in the next few years. It is important to take advantage of this pandemic so that all countries can reconsider their preparations for IT infrastructure to avoid any constraints in the future.

Achieving a sustainable educational system should be considered by educational institutions through implementing the concept of the 'Smart City. This would assist them to achieve a sustainable online system to be used by all stakeholders such as students, teachers, educational staff, and parents. However, the ultimate decision-making must be taken to achieve proper education for all stakeholders who are engaged with online learning.

\section{Reference}

1. Al-Qaoud, F., et al., An International Comparison of Blended Learning. 2020.

2. Lassoued, Z., M. Alhendawi, and R. Bashitialshaaer, An Exploratory Study of the Obstacles for Achieving Quality in Distance Learning during the COVID-19 Pandemic. Education Sciences, 2020. 10(9): p. 232.

3. World Health Organization [cited 202020 Sep 2020].

4. McGee, R.S., et al., Model-driven mitigation measures for reopening schools during the COVID-19 pandemic. medRxiv, 2021.

5. Hanushek, E.A. and L. Woessmann, The economic impacts of learning losses. 2020.

6. American Academy of, P., COVID-19 planning considerations: guidance for school re-entry. Critical Updates on COVID-19-Clinical Guidance, 2020. 2019: p. 1-11.

7. Schweingruber H, D.K., Bond EC, Reopening K-12 Schools During the COVID-19 Pandemic: Prioritizing Health, Equity, and Communities eds, E. National Academies of Sciences, and Medicine, et al., Editors. 2020: Washington (DC).

8. Zimmerman, B.J. and D.H. Schunk, Self-regulated learning and performance. Handbook of self-regulation of learning and performance, 2011: p. 1-12. 
9. Bernard, R.M., et al., A meta-analysis of three types of interaction treatments in distance education. Review of Educational research, 2009. 79(3): p. 1243-1289.

10. Bol, L. and J.K. Garner, Challenges in supporting self-regulation in distance education environments. Journal of Computing in Higher Education, 2011. 23(2): p. 104-123.

11. Cho, M.-H. and Y. Cho, Self-regulation in three types of online interaction: a scale development. Distance Education, 2017. 38(1): p. 70-83.

12. Moore, M.G., Three types of interaction. 1989, Taylor \& Francis.

13. Kernohan, D., Which universities are moving to remote teaching. WONKHE: https://wonkhe. com/blogs/which-universities-are-moving-to-remote-teaching, 2020.

14. Watermeyer, R., et al., COVID-19 and digital disruption in UK universities: Afflictions and affordances of emergency online migration. Higher Education, 2020: p. 1-19.

15. News, B. COVID-19: What's happening with schools?. 2020f, March 21 [cited 2021 12 March 2021].

16. Morgan, J., Schools shutdown creates UK university admissions uncertainty. Times Higher Education, 2020.

17. Bothwell, E., Flexible admissions could mitigate COVID-19 impact. Times Higher Education, 2020.

18. News, B. UK PM Boris Johnson announces closure of pub, bars and restaurants 2020b, March 20 [cited 2021 12, March 2021].

19. Gov.UK. Travel advice: Coronavirus (COVID-19). 2020 [cited 2021 12, March 2021].

20. Dublin, T.C. COVID-19 (Coronavirus). 2020 [cited 2021 12, March 2021].

21. Deeks, A., Message to Students from Presidents of Irish Universities and Institutes of Technology. 2020, Email communication on.

22. Learning, U.T. Teaching Continuity Measures. 2020 [cited 2021 12, March 2021].

23. Cork, U.C. University closure coronavirus (COVID-19) Safety Update 2020 [cited 2021 12, March 2021].

24. Belfast, Q.s.U. COVID-19 (Coronavirus): FAQs for students and staff. . 2020 [cited 2021 12, March 2021].

25. RTE. Coronavirus in Ireland - A timeline. 2020a, March 20 [cited 2021 12, March 2021].

26. Chatziralli, I., et al., Transforming ophthalmic education into virtual learning during COVID-19 pandemic: a global perspective. Eye, 2020: p. 1-8.

27. Heylings, D.J.A., Anatomy 1999-2000: The curriculum, who teaches it and how? Medical education, 2002. 36(8): p. 702-710.

28. Longhurst, G.J., et al., Strength, weakness, opportunity, threat (SWOT) analysis of the adaptations to anatomical education in the United Kingdom and Republic of Ireland in response to the Covid-19 pandemic. Anatomical sciences education, 2020. 13(3): p. 301-311.

29. Bundesamt, S. Hochschulen nach Hochschularten. . 2020 [cited 2021 12, March 2021].

30. Passau, U.o. Coronavirus (COVID-19) - important information. . 2020 [cited 2021 12, March 2021].

31. Göttingen, U. FAQ on the novel coronavirus. 2020 [cited 2021 12, March 2021].

32. Getto, B. and M. Kerres, Akteurinnen/Akteure der Digitalisierung im Hochschulsystem: Modernisierung oder Profilierung? Zeitschrift für Hochschulentwicklung, 2017. 
33. Zawacki-Richter, O., The current state and impact of Covid-19 on digital higher education in Germany. Human Behavior and Emerging Technologies, 2021. 3(1): p. 218-226.

34. University, H. COVID-19 Update: Remote classes, campus closed. . 2020 [cited 2021 12, March 2021].

35. Crawford, J., et al., COVID-19: 20 countries' higher education intra-period digital pedagogy responses. Journal of Applied Learning \& Teaching, 2020. 3(1): p. 1-20.

36. Salute, M.d. New coronavirus. Ministry of Health. . 2020 [cited 2021 12, March 2021].

37. De Giorgio, T., Coronavirus in Lombardy, at the Politecnico di Milano the degree thesis is discussed via Skype. La Repubblica, 2020.

38. Associata)., A.A.N.S. Coronavirus: Thermal scanner at Unibas [Italian]. Basilicata. . 2020, February 26 [cited 2021 12, March 2021].

39. D'Adamo, I. and P. Rosa, How do you see infrastructure? green energy to provide economic growth after COVID-19. 2020, Multidisciplinary Digital Publishing Institute.

40. Tudorie, C.A.-M., et al., Towards a Greener University: Perceptions of Landscape Services in Campus Open Space. Sustainability, 2020. 12(15): p. 6047.

41. Sonetti, G., P. Lombardi, and L. Chelleri, True green and sustainable university campuses? Toward a clusters approach. Sustainability, 2016. 8(1): p. 83.

42. Hone, K.S. and G.R. El Said, Exploring the factors affecting MOOC retention: A survey study. Computers \& Education, 2016. 98: p. 157-168.

43. Zheng, S., et al. Understanding student motivation, behaviors and perceptions in MOOCs

44. Singh, A.B., Learning through massive open online courses (MOOCs): A case of the first international MOO offered by University of Oslo in 2015. 2016.

45. Giovannella, C., Effect induced by the Covid-19 pandemic on students' perception about technologies and distance learning, in Ludic, Co-design and Tools Supporting Smart Learning Ecosystems and Smart Education. 2021, Springer. p. 105-116.

46. Bagshaw, E., Travel warning raised, indoor mass gatherings over 100 people prohibited. Sydney Morning Herald, 2020.

47. Sydney, U.o. Confirmed case of COVID-19. University of Sydney. . 2020 [cited 2021 12, March 2021].

48. University, M. Coronavirus (COVID-19) infection: latest information. . 2020 [cited 2021 12, March 2021].

49. University, M. COVID-19 - fact sheet. Monash University. . 2020 [cited 2021 12, March 2021].

50. University, V. Coronavirus (COVID-19). 2020 [cited 2021 12, March 2021].

51. Queensland, U.o. UQ pauses teaching for one week [email to students]. . 2020 [cited 2021 12, March 2021].

52. Sydney, U.o.T. Coronavirus advice and frequently asked questions. . 2020 [cited 2021 12, March 2021].

53. University, A.N. Information for students - 17 March 2020. . 2020 [cited 2021 12, March 2021].

54. Tasmania, U.o. COVID-19 updates. 2020 [cited 2021 12, March 2021].

55. Organization, W.H. Coronavirus disease (COVID-2019) situation reports. Situation report - 64 (29 March 2020). . 2020a [cited 2021 12, March 2021].

56. Herpich, N., $Q \& A$ on Harvard's move to online learning. Harvard Gazette, 2020. 
57. University, S.O. Important details: for students, about spring break, spring term 2020 [cited 2021 12, March 2021].

58. Bawab, N., Here's what Texas universities and colleges are doing in response to COVID-19. WFAA8 ABC, 2020.

59. Cho, M.-H., J. Cheon, and S. Lim, Preservice teachers' motivation profiles, selfregulation, and affective outcomes in online learning. Distance education, 2021. 42(1): p. 37-54.

60. Pintrich, P.R., A conceptual framework for assessing motivation and self-regulated learning in college students. Educational psychology review, 2004. 16(4): p. 385-407.

61. Shea, P. and T. Bidjerano, Learning presence: Towards a theory of self-efficacy, selfregulation, and the development of a communities of inquiry in online and blended learning environments. Computers \& Education, 2010. 55(4): p. 1721-1731.

62. Artino Jr, A.R. and K.D. Jones Ii, Exploring the complex relations between achievement emotions and self-regulated learning behaviors in online learning. The Internet and Higher Education, 2012. 15(3): p. 170-175.

63. Dörrenbächer, L. and F. Perels, Self-regulated learning profiles in college students: Their relationship to achievement, personality, and the effectiveness of an intervention to foster self-regulated learning. Learning and Individual Differences, 2016. 51: p. 229-241.

64. Mägi, K., M. Männamaa, and E. Kikas, Profiles of self-regulation in elementary grades: Relations to math and reading skills. Learning and Individual Differences, 2016. 51: p. 37-48.

65. Vanslambrouck, S., et al., A latent profile analysis of adult students' online selfregulation in blended learning environments. Computers in Human Behavior, 2019. 99: p. 126-136.

66. Zimmerman, B.J., Investigating self-regulation and motivation: Historical background, methodological developments, and future prospects. American educational research journal, 2008. 45(1): p. 166-183.

67. Chauhan, S., et al., Examining continuance intention in business schools with digital classroom methods during COVID-19: a comparative study of India and Italy. Behaviour \& Information Technology, 2021: p. 1-24.

68. Zhang, W., et al., Suspending classes without stopping learning: China's education emergency management policy in the COVID-19 outbreak. 2020, Multidisciplinary digital publishing institute.

69. Fatimah, F., S. Rajiani, and E. Abbas, Cultural and individual characteristics in adopting computer-supported collaborative learning during covid-19 outbreak: Willingness or obligatory to accept technology? Management Science Letters, 2021. 11(2): p. 373-378.

70. UNESCO. 1.3 billion learners are still affected by school or university closures, as educational institutions start reopening around the world, says UNESCO. 2020 [cited 2021 3/4/2021].

71. Cohen, J. and K. Kupferschmidt, Countries test tactics in 'war'against COVID-19. 2020, American Association for the Advancement of Science.

72. Garbe, A., et al., Parents' experiences with remote education during COVID-19 school closures. American Journal of Qualitative Research, 2020. 4(3): p. 45-65.

73. Southall, E.R., et al., An analysis of school absences in England during the Covid-19 pandemic. MedRxiv, 2021. 
74. Office, U.G.P.M.s. Prime Minister's statement on coronavirus (COVID-19) 2020 [cited 202025 March 2020].

75. Office, U.G.P.M.s. Prime Minister's statement on re-turning children to school (2020). . 2020 [cited 2021 4, April 2021].

76. Office, U.G.P.M.s. Guidance for Schools, coronavirus: COVID-19 (2020). 2020 [cited 2021 4, April 2021].

77. Edmunds, W.J., Finding a path to reopen schools during the COVID-19 pandemic. The Lancet Child \& Adolescent Health, 2020. 4(11): p. 796-797.

78. Selwyn, N., Education in a digital world: Global perspectives on technology and education. 2012: Routledge.

79. McFarlane, A.E., Devices and desires: Competing visions of a good education in the digital age. British Journal of Educational Technology, 2019. 50(3): p. 1125-1136.

80. Fraillon, J., et al., Preparing for life in a digital world: IEA International computer and information literacy study 2018 international report. 2020: Springer Nature.

81. Bildungsberichterstattung, A., Bildung in Deutschland 2020. Ein indikatorengestützter Bericht mit einer Analyse zu Bildung in einer digitalisierten Welt, 2020: p. 40-41.

82. Gew, G.E., Wissenschaft (Hrsg.)(2017): Mehr Flexibilität auf Kosten der Erzieher* innen. CDU und FDP liebäugeln mit anpassungsfähiger Kinderbetreuung. URL: https://www. gewnrw. de/meldungen/detail-meldungen/news/mehr-flexibilitaet-aufkosten-der-erzieherinnen. html, letzter Zugriff, 2020. 5.

83. Kozma, R.B., ICT, education transformation, and economic development: An analysis of the US National Educational Technology Plan. E-Learning and Digital Media, 2011. 8(2): p. 106-120.

84. König, J., D.J. Jäger-Biela, and N. Glutsch, Adapting to online teaching during COVID-19 school closure: teacher education and teacher competence effects among early career teachers in Germany. European Journal of Teacher Education, 2020. 43(4): p. 608-622.

85. Im Kampe, E.O., et al., Surveillance of COVID-19 school outbreaks, Germany, March to August 2020. Eurosurveillance, 2020. 25(38): p. 2001645.

86. Palau, R., et al., Analysis of the implementation of teaching and learning processes at Catalan schools during the Covid-19 lockdown. Technology, Pedagogy and Education, 2021: p. 1-17.

87. Catalunya, G.d. Coronavirus: Comunicats del Departament d'Educació. Departament d'Educació de la Generalitat de Catalunya. . 2020 [cited 2021 12, March 2021].

88. AMETIC, Smart Cities. 2012, Spain. 92.

89. Güell, J.M.F., Ciudades inteligentes: la mitificación de las nuevas tecnologías como respuesta a los retos de las ciudades contemporáneas. Economía industrial, 2015(395): p. 17-28.

90. Paskaleva, K.A., The smart city: A nexus for open innovation? Intelligent Buildings International, 2011. 3(3): p. 153-171.

91. Shapiro, J.M., Smart cities: explaining the relationship between city growth and human capital. Available at SSRN 480172, 2003.

92. Caragliu, A., C. Del Bo, and P. Nijkamp, Smart cities in Europe. Journal of urban technology, 2011. 18(2): p. 65-82.

93. Klein, C. and G. Kaefer. From smart homes to smart cities: Opportunities and challenges from an industrial perspective. Springer. 
94. Olmos-Gómez, M.d.C., et al., Validation of the Smart City as a Sustainable Development Knowledge Tool: The Challenge of Using Technologies in Education during COVID-19. Sustainability, 2020. 12(20): p. 8384.

95. Europeo, P., Mapping smart cities in the EU. POLICY DEPARTMENT A: ECONOMIC AND SCIENTIFIC POLICY. Recuperado de la red mundial desde: http://www. smartcities. at/assets/Publikationen/Weitere-Publikationen-zumThema/mappingsmartcities. pdf, 2014.

96. De Pablos-Pons, J., et al., Teacher well-being and innovation with information and communication technologies; proposal for a structural model. Quality \& quantity, 2013. 47(5): p. 2755-2767.

97. Lepp, L., et al., Teaching during COVID-19: The Decisions Made in Teaching. Education Sciences, 2021. 11(2): p. 47.

98. Haridussilm. Külastatud Aadressil. 2020 [cited 2021 3/4/2021].

99. Estonia, M.o.E.a.R. Haridus-ja Teadusministeerium Soovitab Vähemalt Esimesel Kahel Nädalal Hoiduda Õpilaste Numbrilisest Hindamisest. 2020 [cited 202018 March 2020].

100. Research, M.o.E.a., The Estonian Lifelong Learning Strategy 2020. 2020: Estonia. p. 15.

101. Hamilton, L.S., et al., COVID-19 and the State of K-12 Schools: Results and Technical Documentation from the Spring 2020 American Educator Panels COVID-19 Surveys. RAND Corporation, 2020.

102. Lake, R. and B. Dusseault, Remote classes are in session for more school districts, but attendance plans are still absent. Center on Reinventing Public Education, 2020.

103. Horowitz, J.M., Lower-income parents most concerned about their children falling behind amid COVID-19 school closures. Pew Research Center, 2020.

104. Bacher-Hicks, A., J. Goodman, and C. Mulhern, Inequality in household adaptation to schooling shocks: Covid-induced online learning engagement in real time. Journal of Public Economics, 2021. 193: p. 104345.

105. Calhoun, K.E., et al., The impact of COVID-19 on medical student surgical education: implementing extreme pandemic response measures in a widely distributed surgical clerkship experience. The American Journal of Surgery, 2020. 220(1): p. 44-47.

106. Bol, T., Inequality in homeschooling during the Corona crisis in the Netherlands. First results from the LISS Panel. 2020.

107. Domina, T., et al., Remote or Removed: Predicting Successful Engagement with Online Learning during COVID-19. Socius, 2021. 7: p. 2378023120988200.

108. Doyumğaç, İ., A. Tanhan, and M.S. Kiymaz, Understanding the most important facilitators and barriers for online education during COVID-19 through online photovoice methodology. International Journal of Higher Education, 2020. 10(1): p. 2021.

109. Stacey*, E., P.J. Smith, and K. Barty, Adult learners in the workplace: Online learning and communities of practice. Distance Education, 2004. 25(1): p. 107-123.

110. Fatonia, N.A., et al., University students online learning system during Covid-19 pandemic: Advantages, constraints and solutions. Systematic Reviews in Pharmacy, 2020. 11(7): p. 570-576.

111. Lee, Y.-H., C. Hsiao, and C.-H. Ho, The effects of various multimedia instructional materials on students' learning responses and outcomes: A comparative experimental study. Computers in Human Behavior, 2014. 40: p. 119-132. 
112. Hennessy, S., R. Deaney, and K. Ruthven, Situated expertise in integrating use of multimedia simulation into secondary science teaching. International Journal of Science Education, 2006. 28(7): p. 701-732.

113. Ali, W., Online and remote learning in higher education institutes: A necessity in light of COVID-19 pandemic. Higher Education Studies, 2020. 10(3): p. 16-25.

114. Hatzigianni, M. and I. Kalaitzidis, Early childhood educators' attitudes and beliefs around the use of touchscreen technologies by children under three years of age. British Journal of Educational Technology, 2018. 49(5): p. 883-895.

115. Dameri, R.P., Searching for smart city definition: a comprehensive proposal. International Journal of computers \& technology, 2013. 11(5): p. 2544-2551.

116. Katoshevski-Cavari, R., T.A. Arentze, and H.J.P. Timmermans, Sustainable city-plan based on planning algorithm, planners' heuristics and transportation aspects. Procedia-Social and Behavioral Sciences, 2011. 20: p. 131-139.

117. Kirimtat, A., et al., Future trends and current state of smart city concepts: A survey. IEEE Access, 2020. 8: p. 86448-86467.

118. Caragliu, A., C.D. Bo, and P. Nijkamp, Smart Cities in Europe «3rd Central European Conference in Regional Science-CERS. A13 L, 2009. 90: p. O18.

119. Chen, Y.-T., Sketch industry promotion framework for smart living services by leveraging living lab harmonization cube. International Journal of Electronic Business Management, 2012. 10(2): p. 149.

120. Cosgrave, E. and T. Tryfonas. Exploring the relationship between smart city policy and implementation.

121. Dameri, R.P. Defining an evaluation framework for digital cities implementation. IEEE.

122. Gretzel, U., et al., Conceptual foundations for understanding smart tourism ecosystems. Computers in Human Behavior, 2015. 50: p. 558-563.

123. Maheshwari, D. and M. Janssen, Reconceptualizing measuring, benchmarking for improving interoperability in smart ecosystems: The effect of ubiquitous data and crowdsourcing. Government Information Quarterly, 2014. 31: p. S84-S92.

124. Lytras, M.D. and A. Visvizi, Who uses smart city services and what to make of it: Toward interdisciplinary smart cities research. Sustainability, 2018. 10(6): p. 1998. 